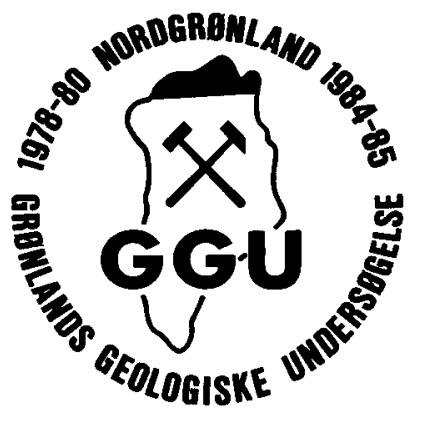

\title{
Lowermost Ordovician sandstones in central North Greenland
}

\author{
Ian D. Bryant and M. Paul Smith
}

\begin{abstract}
A prominent cliff-forming white sandstone occurs within the thick sequence of Cambro-Ordovician carbonate sediments in western North Greenland. The unit has been traced from Nares Land to Warming Land, attaining a maximum thickness of $53 \mathrm{~m}$, and is here named the Permin Land Formation. A thinner sandstone (maximum thickness $15 \mathrm{~m}$ ) occurs within the upper part of the Cass Fjord Formation of Daugaard-Jensen Land and is named the Kap Coppinger Member of that formation. These units are considered to be coeval and of early Ibexian (earliest Ordovician) age.
\end{abstract}

I. D. B., Department of Geology, University of Nottingham, University Park, Nottingham NG7 2RD, England. Present address: K. S. E. P. L., Postbus 60, 2280 AB, Rijswijk (ZH), Holland.

M. P. S., Department of Geology, University of Nottingham, University Park, Nottingham NG7 2RD, England.

The Lower Palaeozoic platform strata of central and western North Greenland are predominantly composed of carbonate sedimentary rocks (Peel, 1980, 1982). Thin sandstones and sandy carbonates have, however, been reported from the Cambrian and Ordovician strata of Daugaard-Jensen Land (Henriksen \& Peel, 1976), Warming Land and Wulff Land. In the latter two areas a prominent, $40 \mathrm{~m}$ thick sandstone was informally termed the 'white marker sandstone' by Peel (1980) who thought that, to the west, it might be correlated with one of several similar sandstones in the Cass Fjord, Christian Elv and Poulsen Cliff Formations. It was further suggested by Peel (1980) that the sandstone might be a correlative of white sandstones which occur in the upper part of formation T3 (Ineson \& Peel, 1980) of the Tavsens Iskappe Group.

Geological mapping during the 1984 field season showed the 'white marker sandstone' to be an important mapping horizon in the area between southern Nares Land in the east and western Daugaard-Jensen Land in the west (fig. 1). In Nares Land, Wulff Land and Warming Land, where it occurs as a prominent cliff-forming unit up to $53 \mathrm{~m}$ thick, we propose to name this sandstone the Permin Land Formation after its occurrence on Permin Land (fig. 2). There is no outcrop of the unit between Steensby Gletscher and Petermann Gletscher, but in Daugaard-Jensen Land a thinner white sandstone is present within the Cass Fjord Formation of Poulsen (1927). We regard this sandstone to be the western correlative to the Permin Land Formation and it is named herein the Kap Coppinger Member of the Cass Fjord Formation. 


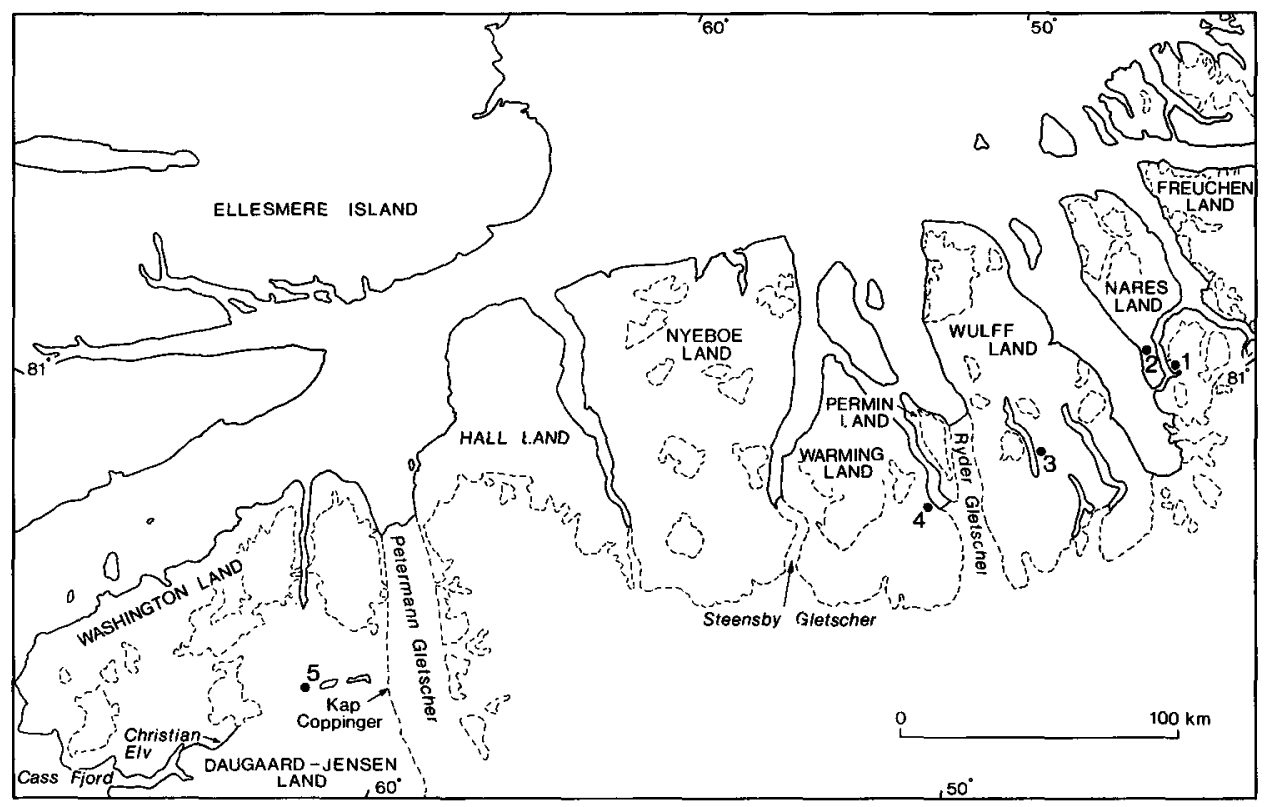

Fig. 1. Location map to show the areas discussed in the text and the positions of the logged sections recorded in fig. 3 .

\section{Permin Land Formation}

General. The formation is equivalent to the informally defined 'white marker sandstone' of Peel (1980).

Name. After Permin Land (fig. 1), along the sides of which the formation is well-exposed and approaches its thickest development.

Type section. Cliffs on the eastern coast of central Warming Land immediately adjacent to the southern tip of Permin Land (fig. 1, locality 4).

Thickness. $53 \mathrm{~m}$ (maximum) at the type section (fig. 3, locality 4). This thickness is maintained throughout Warming Land but the formation thins eastwards to a minimum thickness of $12 \mathrm{~m}$ in Nares Land (fig. 3, locality 2).

Lithology. The formation is predominantly composed of clean, well-sorted fine to medium grained quartz sand. The majority of the beds are parallel-sided, medium-bedded, and laterally persistent over several kilometres. A wide variety of sedimentary structures occur within the formation; trough and planar tabular cross-bedding, wave ripple lamination, flat and low angle lamination. Thin beds of dolomite occur within the sandstones and in Nares Land (fig. 1 , locality 1) shales are also present. Sandstone beds overlying the dolomites commonly pos- 


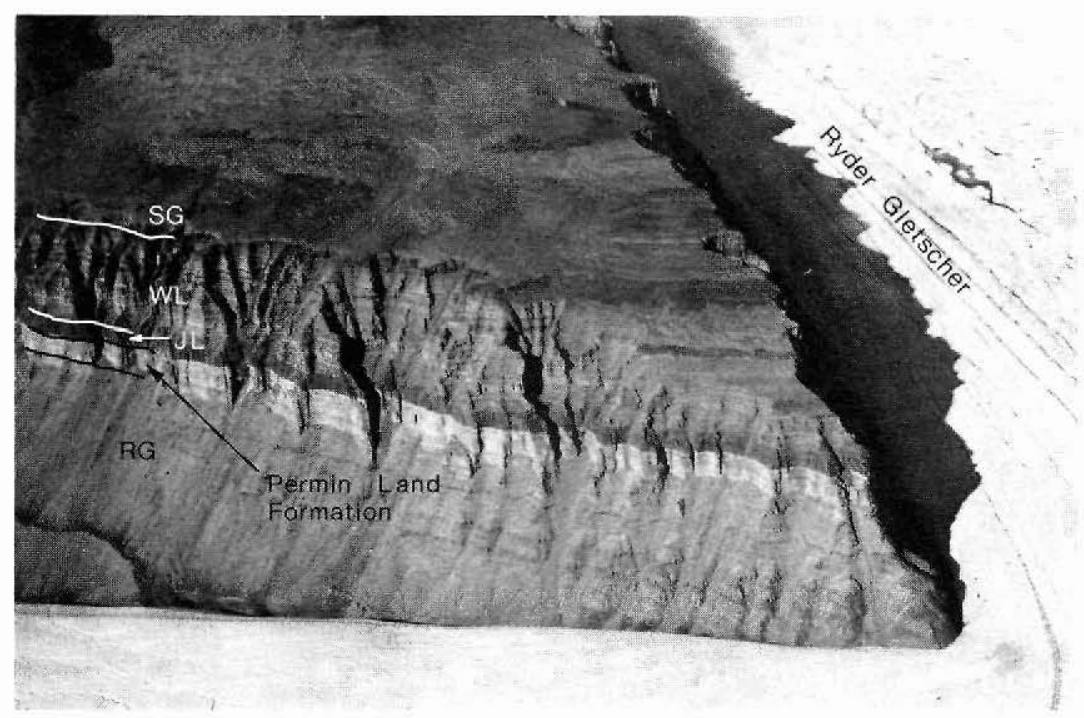

Fig. 2. Southern tip of Permin Land showing the Permin Land Formation in its characteristic weathering form, as a very pale, cliff-forming unit. RG: Ryder Gletscher Group; JL: Johansen Land Formation; WL: Warming Land Formation; SG: Steensby Gletscher Formation.

sess scoured bases and contain dolomite pebbles. Evidence of burrowing is also apparent at some horizons, where it is usually confined to the upper parts of individual beds.

Boundaries. Thin sandstones have been recorded from the underlying carbonate formations of the Ryder Gletscher Group (Peel \& Wright, 1985). For this reason the base of the formation is taken at the base of the first sandstone over $10 \mathrm{~m}$ thick. In theory this might make unequivocal recognition of the formation difficult (if, for example, the sandstone was faulted) but in practice the sandstone is readily distinguished from the much thinner underlying sands. The upper boundary of the formation is gradational over approximately $1 \mathrm{~m}$ (but is very sharp at the mapping scale) and is overlain by liver-brown sandy dolomites of the Johansen Land Formation (Sønderholm \& Due, 1985), which locally contain digitate stromatolites. The association of a thick, pale-weathering sandstone overlain by a liver-brown dolomite is unique within the sediments of the region. A similar, but thinner and more geographically restricted sandstone unit occurs higher in the sequence and is described by Sønderholm \& Due (1985) as the Røhling Land Member of the Warming Land Formation.

Distribution. The formation outcrops from south-eastern Nares Land and adjacent areas to the Steensby Gletscher at the western edge of Warming Land.

\section{Kap Coppinger Member}

General. The member occurs within the upper $50 \mathrm{~m}$ of the Cass Fjord Formation of Washington Land and Daugaard-Jensen Land (fig. 4). 


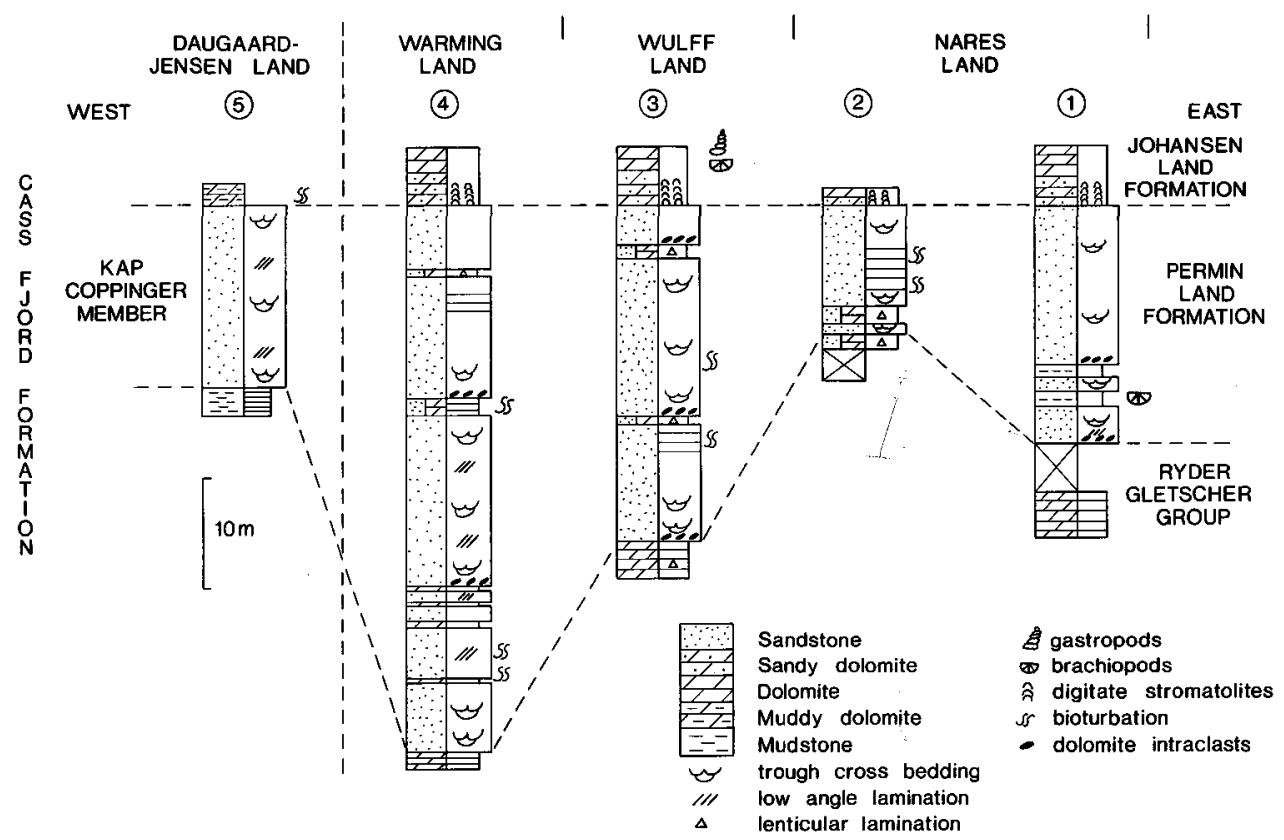

Fig. 3. Sections through the Permin Land Formation and the Kap Coppinger Member of the Cass Fjord Formation. Location of the sections is shown in fig. 1. Section 4 is the type section of the Permin Land Formation; section 5 is the type section of the Kap Coppinger Member.

Name. After the cliffs at the western margin of the Petermann Gletscher, where the member is exposed.

Type section. Cliffs $25 \mathrm{~km}$ west of Kap Coppinger, on the southern side of the major eastwest valley containing two large lakes (fig. 1 , locality 5 ).

Thickness. $15 \mathrm{~m}$ at the type section (fig. 3, locality 5) thinning westward to $1.5 \mathrm{~m}$ in the Cass Fjord area (J. S. Peel, personal communication).

Lithology. The member is lithologically indistinguishable from the Permin Land Formation and contains a similar suite of sedimentary structures.

Boundaries. The member is underlain by dolomite shales with subordinate beds of flake conglomerates. (A $3 \mathrm{~m}$ thick sandstone occurs $28 \mathrm{~m}$ below the base of the member at the type locality.) The top metre of the member consists of bioturbated dolomitic sandstones with flake conglomerates. It is overlain by thinly bedded micrites with silty interbeds and abundant flake breccias of typical Cass Fjord Formation lithologies. Bedding surfaces in this overlying unit display abundant trace fossils and some ripple marks.

Distribution. The member can be traced from the eastern side of the Petermann Gletscher in the east to the Cass Fjord area in the west. 


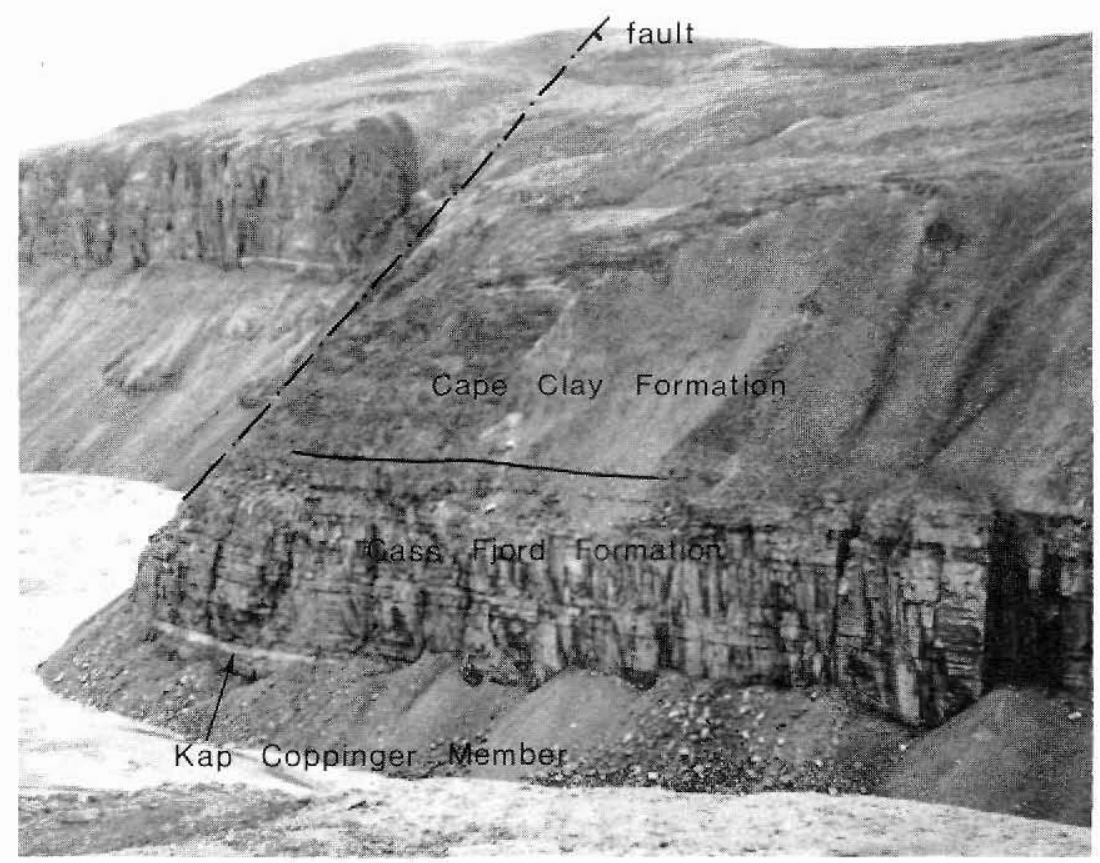

Fig. 4. The Kap Coppinger Member $(1.5 \mathrm{~m})$ of the Cass Fjord Formation at Christian Elv. View looking west towards Cass Fjord. Photo: Niels Henriksen.

\section{Stratigraphic age of the Permin Land Formation and the Kap Coppinger Member}

Gastropods and brachiopods were collected in the Johansen Land Formation $10.1 \mathrm{~m}$ above the top of the Permin Land Formation (Sønderholm \& Due, 1985) in Wulff Land (fig. 1, locality 3 ). These were identified by J. S. Peel as Helicotoma? and Finkelnburgia? multicostata (Poulsen); the latter has previously only been recorded from the Cape Clay Formation of Daugaard-Jensen Land (Poulsen, 1927).

Conodont samples collected in 1984 close to the boundaries of the Permin Land Formation have not yet been processed but, in 1975, samples were collected by Niels Henriksen and J. S. Peel (GGU) above and below the Kap Coppinger Member at Christian Elv, Daugaard-Jensen Land. The single sample $4 \mathrm{~m}$ below the sandstone contains 'Paltodus' bassleri, whilst more diverse faunas from the overlying upper beds of the Cass Fjord Formation and the Cape Clay Formation contain 'P.' bassleri, Clavohamulus densus, Cordylodus angulatus, Cordylodus intermedius and Teridontus nakamurai with a single occurrence of Loxodus bransoni $65 \mathrm{~m}$ above the sandstone. This fauna is similar in all aspects to that described from the Cape Clay Formation of southern Devon Island by Landing \& Barnes (1981).

The conodonts from above and below the Kap Coppinger Member are indicative of the uppermost Cordylodus intermedius Interval or Loxodus bransoni Interval (early Ibexian) in the zonal scheme of Ethington \& Clark (1982). The presence of the brachiopod F.? multicostata in both the Cape Clay and Johansen Land Formations is consistent with a similar early Ibexian age (earliest Ordovician) for the Permin Land Formation. 
Acknowledgements. The conodont samples were processed by V. E. Kurtz and J. F. Miller in connection with an earlier, unpublished study of Early Ordovician conodonts from Daugaard-Jensen Land and Washington Land; specimens have been re-determined here. J. S. Peel identified the macrofauna. R. J. Aldridge critically read the manuscript which was typed by J. Angell.

\section{References}

Ethington, R. L. \& Clark, D. L. 1982: Lower and Middle Ordovician conodonts from the Ibex area, western Millard County, Utah. Brigham Young Univ. Geol. Stud. 28(2), 160 pp.

Henriksen, N. \& Peel, J. S. 1976: Cambrian - Early Ordovician stratigraphy in south-western Washington Land, western North Greenland. Rapp. Grønlands geol. Unders. 80, 17-23.

Ineson, J. R. \& Peel, J. S. 1980: Cambrian stratigraphy in Peary Land, eastern North Greenland. Rapp. Grønlands geol. Unders. 99, 33-42.

Landing, E. \& Barnes, C. R. 1981: Conodonts from the Cape Clay Formation (Lower Ordovician), southern Devon Island, Arctic Archipelago. Can. J. Earth Sci. 18, 1609-1628.

Peel, J. S. 1980: Cambrian and Ordovician geology of Warming Land and southern Wulff Land, central North Greenland. Rapp. Gronlands geol. Unders. 101, 55-60.

Peel, J. S. 1982: The Lower Paleozoic of Greenland. Mem. Can. Soc. Petrol. Geol. 8, 309-330.

Peel, J. S. \& Wright, S. C. 1985: Cambrian platform stratigraphy in the Warming Land - Freuchen Land region, North Greenland. Rapp. Grønlands geol. Unders. 126, 17-24.

Poulsen, C. 1927: The Cambrian, Ozarkian and Canadian faunas of North-west Greenland. Meddr Grønland 70(1), 2, 233-343.

Sønderholm, M. \& Due, P. H. 1985: Lower and Middle Ordovician platform carbonate lithostratigraphy of Warming Land, Wulff Land and Nares Land, North Greenland. Rapp. Grønlands geol. Unders. 126, 31-46. 